\title{
HUBUNGAN HIPERTENSI DENGAN FUNGSI KOGNITIF PADA LANSIA DI UPTD PANTI SOSIAL REHABILITASI LANJUT USIA DAN PEMELIHARAAN MAKAM PAHLAWAN CIPARAY KABUPATEN BANDUNG
}

\author{
${ }^{1)}$ Eka Suci Wulandari, ${ }^{2)}$ Erlina Fazriana, ${ }^{3)}$ Shinta Apriani \\ 1) 2) Program Studi Sarjana Keperawatan STIKes Dharma Husada Bandung \\ wulanul.eka01@gmail.com ; erlina.fazriana@yahoo.com; \\ 3) program studi Diploma tiga keperawatan STIKes Dharma Husada Bandung \\ shintaaprianai1@gmail.com
}

\begin{abstract}
Abstrak
Hipertensi merupakan salah satu penyakit yang sering dialami lansia. Salah satu komplikasi hipertensi pada sistem syaraf pusat selain stroke juga dapat menyebabkan penurunan fungsi kognitif. Pada tahun 2016 di Jawa Barat ditemukan 790.382 orang dengan kasus hipertensi (2,46\% terhadap jumlah penduduk $\geq 18$ tahun), dengan jumlah kasus yang diperiksa sebanyak 8.029.245 orang, tersebar di 26 Kabupaten/Kota. Tujuan penelitian ini untuk mengetahui hubungan hipertensi dengan fungsi kognitif pada lansia di UPTD Panti Rehabilitasi Lanjut Usia dan Pemeliharaan Makam Pahlawan Ciparay Kabupaten Bandung. Jenis penelitian ini deskriptif korelasi dengan pendekatan cross sectional. Populasi penelitian ini sebanyak 35. Metode pengambilan sampel menggunakan total sampling dengan jumlah 35 responden. Intrumen penelitian menggunakan lembar observasi tekanan darah dan kuisioner mini mental state examination (MMSE). Hasil penelitian menunjukan bahwa lansia yang mengalami hipertensi terbanyak berada pada stage 1 sebanyak $21(60,0 \%)$, fungsi kognitif lansia normal sebanyak $22(62,9 \%)$. Hasil analisis uji statistik menggunakan spea-rman rank didapatkan hubungan hipertensi dengan fungsi kognitif lansia memiliki nilai $\rho$-value $0,022(<0,05)$. Dimana terdapat hubungan antara hipertensi dengan fungsi kognitif pada lansia.
\end{abstract}

Kata kunci: hipertensi, fungsi kognitif, lansia

\begin{abstract}
Hypertension are one of diseases that occurred on elderly. One of complication of hypertension on center nerve system beside stroke could decrease cognitive function. On years 2016 in West Java found that 790.382 patient with hypertension $(2,46 \%$ on people $\geq 18$ years old $)$, with total cases examined 8.029.245 patients, spread in 26 Regency

/ City. Purpose from this research to determine relationship of hypertension with cognitive function on elderly in UPTD Elderly Rehabilitation Home and Heroes Cemetery Maintenance Ciparay Bandung. Research type were correlation descriptive with cross sectional approach. Population on this research total 35 respondents. Sampling method used total sampling with 35 respondents. Research instrument used blood pressure observation sheet and mini mental state examination (MMSE) questionnaire. Result research showed that elderly that suffered hypertension most at stage 1 as much 21 (60,0\%), elderly with normal cognitive function as much 22 (62,9\%). Analysis result of statistical test using spearman rank obtained that relationship hypertension and elderly cognitive function p-Value 0,022 $(<0,05)$. There were relationship between hypertension with cognitive function on elderly.
\end{abstract}

Keywords: hypertension, coginitive function, elderly 


\section{PENDAHULUAN}

Lanjut usia atau lansia adalah suatu kejadian yang pasti akan dialami oleh semua orang yang dikaruniai usia panjang. World popukation prospect meyebutkan bahwa populasu penduduk dunia yang berusia 60 tahun atau lebih mencapai 900 juta jiwa yang terdiri atas $12 \%$ populasi dunia. Permasalahan yang berkaitan dengan berlangsungnya proses menjadi tua ialah timbulnya perubahanperubahan fisik, kognitif, perasaan, sosial, dan seksal (Azizah, 2012). Salah satu penyakit yang banyak dialami oleh lansia hipertensi. Hipertensi meningkatkan resiko dua kali lipat terjadinya penyakit jantung koroner dan tiga kali lipat terjadinya gagal jantung dan stroke (Rubattu S, Pagliaro B, dkk, 2014).

Menurut National Health and Nutrition Examination Survey menunjukan bahwa tahun 2011- 2012, prevalensi hipertensi dikalangan orang dewasa Amerika yang berusia 18 tahun keatas yaitu $29,1 \%$ dan hampir sama antara laki-laki $(29,7 \%)$ dan perempuan $(28,5 \%)$ dan diantara orang dewasa Amerika dengan hipertensi, $82,8 \%$ menyadari hipertensi, dan $75,5 \%$ minum obat untuk menurunkan tekanan darah (Nwanko et al, 2013)Pada tahun 2016 di Jawa Barat ditemukan 790.382 orang dengan kasus hipertensi $(2,46 \%$ terhadap jumlah penduduk $\geq 18$ tahun), dengan jumlah kasus yang diperiksa sebanyak 8.029.245 orang, tersebar di 26 Kabupaten/Kota.

Salah satu komplikasi hipertensi pada system syaraf pusat selain stroke juga dapat menyebabkan penurunan fungsi kognitif.
Keadaan penurunan kognitif pada lanjut usia lebih sering didapatkan pada hipertensi kronik. Hal ini terjadi akibat penyempitan dan sklerosis arteri kecil didaerah subkortikal yang mengakibatkan hipoperfusi, kehilangan autoregulasi, penurunan sawar otak, dan pada akhirnya akan terjadi proses demyelinisasi white matter subcortical, mikroinfark, dan penurunan kognitif (Suhardjono, 2009).

\section{TINJAUAN PUSTAKA}

\section{Lansia}

Lanjut usia adalah kelompok yang sedang mengalami suatu proses perubahan yang bertahap dalam jangka waktu beberapa dekade (Notoadmodjo, 2010). Menjadi tua merupakan proses alamiah, yang berarti seseorang telah melalui tiga tahap dalam kehidupannya, yaitu anak, dewasa, dan tua. Tiga tahap ini berbeda, baik secara biologis atau psikologis (Nugroho, 2016). Menurut Peraturan Pemerintah Nomer 43 Tahun 2004 yang dimaksud dengan lanjut usia adalah seseorang yang telah mencapai usia 60 tahun keatas (Kemenkes RI, 2017). Lanjut usia adalah kelompok yang sedang mengalami suatu proses perubahan yang bertahap dalam jangka waktu beberapa dekade (Notoadmodjo, 2010).

\section{Fungsi kognitif}

Fungsi kognitif adalah kemampuan berpikir dan memberikan rasional, termasuk proses belajar, mengingat menilai, orientasi, persepsi dan memperhatikan (Reuser, dkk, 
2010). Fungsi kognitif diartikan sebagai suatu proses semua masukan sensoris (taktil, visual dan auditori) akan diubah, diolah, disimpan yang selanjutnya digunakan untuk hubungan interneuron secara sempurna sehinga individu bisa melakukan penalaran terhadap masukan sensoris tersebut. Fungsi kognitif berhubungan dengan kualitas pengetahuan yang dimiliki seseorang (Wiyoto 2012 dalam Ekasari dkk, 2018).

Aspek aspek yang ada pada fungsi kognitif meliputi orientasi, bahasa, atensi, mengingat segera, konsentrasi memori, fungsi kostruksi, kalkulasi dan penalaran (Ekasari dkk 2018).

\section{Hipertensi}

Hipertensi atau tekanan darah tinggi adalah peningkatan tekanan darah sistolik lebih dari $140 \mathrm{mmHg}$ dan tekanan darah diastolik lebih dari $90 \mathrm{mmHg}$ pada dua kali pengukuran dengan selang waktu lima menit dalam keadaan cukup istirahat/tenang (Kemenkes, 2014). Klasifikasi hipertensi menurut Eighth Joint National Committee (JNC-8) membagi klasifikasi tekanan darah orang dewasa sebagai klasifikasi normal (tekanan darah sistolik di bawah 120 $\mathrm{mmHg}$ dan tekanan darah diastolik di bawah $80 \mathrm{mmHg}$ ), pre-hipertensi (tekanan darah sistolik berkisar dari 120-139 mmHg atau tekanan darah diastolik berkisar dari 80-89 mmHg), hipertensi derajat 1 (tekanan darah sistolik berkisar dari 140$159 \mathrm{mmHg}$ atau tekanan darah diastolik berkisar dari 90-99 $\mathrm{mmHg}$ ), dan hipertensi derajat 2 (tekanan darah sistolik lebih dari atau sama dengan $160 \mathrm{mmHg}$ atau tekanan darah diastolik lebih dari atau sama dengan $100 \mathrm{mmHg}$ ) (Mallidi J, dkk, 2013).

\section{METODE PENELITIAN}

Penelitian yang dilakukan di UPTD panti rehabilitasi lanjut usia dan pemeliharaan makam pahlawan ciparay kabupaten bandung. Penelitian ini berjenis deskriptif korelasi dengan pendekatan cross sectional. Populasi penelitian ini berjumlah 35 lansia dimana lansia yang berusia 60-70 tahun, dapat berkomunikasi dengan baik. Pada penelitian ini menggunakan total sampling dimana sebanyak 35 lansia dijadikan sampel penelitian.

Instrument yang digunakan ialah lembar observasi tekanan darah dan instrument MMSE (Mini Mental State Examination). Penentuan penilaian fungsi kognitif dengan MMSE skor: 30-24 normal, skor 23-17: proable fungsi kognitif, skor 16-0: definitif gangguan kognitif. analisa data yang digunakan yaitu analisa univariate dan bivariate. Analisis bivariate menggunakan uji spearman rank untuk mengetahui ada hubungan atau tidak ada hubungan antara hipertensi dengan fungsi kognitif pada lansia.

Etika penelitian dimulai dari 
JURNAL SEHAT MASADA VOLUME XIII NOMOR 2 Juli 2019 ISSN : 1979-2344

menjelaskan maksud dan tujuan selanjutnya

meminta persetujuan denggan memberikan

informed consents, menjaga kerahasiaan,

keadilan dan keterbukaan.

\section{HASIL PENELITIAN}

Analisa univriat

\section{Hipertensi}

\section{Tabel 4.1 Distribusi Frekuensi Tingkatan Hipertensi Pada Lansia}

\begin{tabular}{lcc}
\hline \multicolumn{1}{c}{ Hipertensi } & Frekuensi & \% \\
\hline Prehipertendi & 6 & 17,1 \\
\hline Hipertensi stage 1 & 21 & 600 \\
\hline Hipertensi stage 2 & 8 & 22,9 \\
\hline Total & $\mathbf{3 5}$ & $\mathbf{1 0 0 , 0}$ \\
\hline
\end{tabular}

Tabel 4.1 berisi tentang distribusi frekuensi tingkatan hipertensi pada lansia. Tingkatan hipertensi terbanyak berada pada tingkat hipertensi stage 1 sebanyak 21 responden $(60,0 \%)$.

\section{Fungsi Kognitif}

\section{Tabel 4.2 Distribusi Frekuensi Fungsi Kognitif Pada Lansia}

\begin{tabular}{lcc}
\hline Fungsi Kognitif & Frekuensi & $\%$ \\
\hline Normal & 22 & 62,9 \\
\hline $\begin{array}{l}\text { Kemungkinan Gangguan } \\
\text { Kognitif }\end{array}$ & 12 & 34,2 \\
\hline $\begin{array}{l}\text { Definitif Gangguan } \\
\text { Kognitif }\end{array}$ & 1 & 2,9 \\
\hline Total & 35 & 100,0 \\
\hline
\end{tabular}

Berdasarkan tabel 4.2 tentang fungsi kognitif pada lansia terbanyak berada pada fungsi kognitif normal sebanyak 22 responden $(62.9 \%)$.

\section{Analisis Bivariat}

Tabel 3 Hubungan Hipertensi dengan Fungsi Kognitif pada Lansia

\begin{tabular}{|c|c|c|c|c|c|c|c|c|c|}
\hline \multirow[t]{3}{*}{ Hipertensi } & \multicolumn{8}{|c|}{ Fungsi Kognitif } & \multirow{3}{*}{$\begin{array}{c}\text { P- } \\
\text { Value }\end{array}$} \\
\hline & \multicolumn{2}{|c|}{ Normal } & \multicolumn{2}{|c|}{$\begin{array}{c}\text { Kemungkinan } \\
\text { Gangguan Kognitif }\end{array}$} & \multicolumn{4}{|c|}{ Definiti } & \\
\hline & $\mathbf{N}$ & $\%$ & $\mathbf{N}$ & $\%$ & $\mathbf{N}$ & $\%$ & $\mathbf{N}$ & $\%$ & \\
\hline Prehipertendi & 5 & 14,3 & 1 & 2,9 & 0 & 0 & 6 & 17,1 & \multirow{4}{*}{0,022} \\
\hline Hipertensi stage 1 & 15 & 42,9 & 5 & 114,3 & 1 & 2,9 & 21 & 60 & \\
\hline $\begin{array}{l}\text { Hipertensi } \\
\text { stage } 2\end{array}$ & 2 & 5,7 & 6 & 17,3 & 0 & 0 & 8 & 22,9 & \\
\hline Total & 22 & 62,9 & 12 & 34,3 & 1 & 2,9 & 35 & 100 & \\
\hline
\end{tabular}

Berdasarkan tabel 3 hasil analisa data dengan menggunakan uji statistik didapatkan hasil uji spearman rank terdapat hubungan yang signifikan antara hipertensi dengan fungsi kognitif pada lansia dengan nilai $\rho 0.022$ $(<0.05)$. Kekuatan hubungan (koefisien korelasi) variabel hipertensi dengan fungsi kognitif cukup dengan nilai koefisien korelasi 0.387. Nilai koefisien korelasi bernilai positif yang menunjukan bahwa korelasi searah. 


\section{PEMBAHASAN}

\section{Analisa univariate}

\section{Hipertensi Pada Lansia}

Faktor-faktor penyebab hipertensi terbagi menjadi dua yaitu faktor yang tidak dapat dikontrol dan faktor yang dapat dikontrol.. Faktor usia merupakan faktor yang tidak dapat dikontrol terhadap hipertensi karena dengan bertambahnya usia maka semakin tinggi mendapat resiko hipertensi. Hal ini sering disebabkan oleh perubahan alamiah didalam tubuh yang mempengaruhi jantung, pembuluh darah dan hormon (Julianti, 2005). Seseorang yang telah berusia lanjut cenderung tekanan darah sistoliknya bertambah tinggi hal ini disebabkan karena menebalnya dinding pemburuh darah dan juga menjadi kaku. (Soetrisno, 2008). Laki-laki beresiko lebih tinggi terkena hipertensi pada masa muda sedangkan wanita akan lebih tinggi terkena hipertensi setelah usia 55 tahun karena akan mengalami menopause (Depkes RI, 2010). Wanita yang belum mengalami menopause akan dilindungi oleh hormone estrogen yang berperan dalam meningkatkan kadar High Density Lipoprotein (HDL). Kadar kolesterol HDL yang tinggi merupakan faktor pelindung dalam mencegah terjadinya proses aterosklerosis. (Kumar et al, 2005 dalam Nuraini, 2015).

Selain itu kegiatan merokok juga lebih banyak dilakukan oleh laki-laki. Hal ini bisa menyebabkan terjadinya hipertensi. Menurut Depkes RI (2006) menyebutkan bahwa zat-zat kimia beracun yang dihisap darah dapat merusak lapisan endotel pembuluh darah tinggi. Merokok juga meningkatkan denyut jantung dan kebutuhan oksigen untuk disuplai ke otototot jantung. Merokok pada penderita darah tinggi akan meningkatkan resiko kerusakan pada pembuluh darah arteri (Depkes RI,2006). Penelitian yang dilakukan oleh Pitriani et al, 2018 meyebutkan bahwa lansia dengan kebiasaan merokok akan beresiko 96,8 kali untuk mengalami hipertensu dibandingkan lansia yang tidak merokok.

Penelitian yang dilakukan oleh Wahyuningsih \& Astuti (2013) menyebutkan bahwa faktor-faktor yang mempengaruhi hipertensi pada lanjut usia di Dusun Kabregan, Bantul Yogyakarta antara lain umur, obesitas, kebiasaan olahraga, stress, kebiasaan merokok, kebiasaan minum kopi dan konsumsi garam sangat berpengaruh terhadap kejadian hipertensi.

\section{Fungsi Kognitif Pada Lansia}

Hasil penelitian mengenai fungsi kognitif pada lansia dengan menggunakan MMSE berada pada kategori normal sebanyak 22 responden (62.9\%) sedangkan yang mengalami kemungkinan gangguan kognitif sebanyak 12 (34.3\%). Penelitian ini sejalan dengan yang dilakukan oleh Gustami (2017) yang meneliti fungsi 
kognitif pada lansia mendapat subjek yang memiliki gangguan kognitif sebanyak 29 $(40,3 \%)$ yang jumlahnya lebih sedikit dibandingkan yang normal $38(77,5 \%)$.

Selain itu dilihat berdasarkan pemeriksaan fungsi kognitif lansia menggunakan MMSE, didapatkan hasil banyaknya lansia mengalami penurunan bagian memori dimana pada pertanyaan mengenai mengingat kembali beberapa lansia tidak dapat menyebutkan benda yang telah disebutkan sebelumya. Hal ini berkaitan dengan kemampuan memori pada lansia dimana memori kerja dan kecepatan perseptual mengalami penurunan. Pada pertanyaan atensi dan kalkulasi juga terdapat beberapa lansia yang mengalami kesulitan saat menjawab pertanyaan yang diajukan. Atensi sendiri merupakan kemampuan seseorang merespon stimulus spesifik dengan mengabaikan stimulus yang lain diluar lingkungannya (Santrock, 2017).

Neurosains kognitif dimana perubahan yang berlangsung diotak dapat mempengaruhi fungsi kognitif dan perubahan-perubahan fungsi kognitif dapat mempengaruhi otak (Smith, 2007 dalam Santrock 2012). Apabila seorang lansia tidak menggunakan working memory mereka secara teratur maka koneksikoneksi neural yang terjadi di lobus prefrontal dapat mengalami atropi.

\section{Hubungan Hipertensi dengan Fungsi Kognitif pada Lansia}

Faktor faktor yang berhubungan dengan fungsi kognitif pada lansia meliputi: usia, stress depresi dan ansietas, latihan memori, genetik, hormon, lingkungan, penyakit sistemik, intoksikasi obat. Salah satu penyakit sistemik adalah hipertensi. Hipertensi dapat menjadi faktor resiko terhadap fungsi kognitif pada lansia. Penyakit hipertensi merupakan salah satu penyakit kardiovaskular yang banyak dialami oleh lansia. Hipertensi memiliki dampak signifikan pada fungsi kardiovaskular, integritas strukturai otak dan kemunduran kognitif terutama pada individu yang tidak mengkonsumsi obat antihipertensi. (Killander, dkk (1998) dalam Taraghi et al (2016)).

Hipertensi yang kronis akan menyebabkan sel otot polos pembuluh darah otak berpoliferasi. Komplikasi hipertensi yang berkaitan dengan otak adalah terjadinya remodeling vascular sehingga terjadi gangguan autoregulasi cerebral, lesi di substansa alba, infark lacunar dan perubahan otak yang mirip penderita demensia alzheimer seperti amyloid dan atropi cerebral. Semakin lama jika dibiarkan maka akan semakin memperparah lesi di substansia alba maupun infark lacunar, sehingga gangguan fungsi kognitif akan semakin berat (Manolio \&Olson, 2003).

Hasil penelitian yang dilakukan oleh 
Wahyuniarti, et al (2013) dengan judul hubungan hipertensi dengan penurunan fungsi kognitif pada lansia didapatkan hasil bahwa lansia yang mengalami gangguan pada penderita hipertensi, penderita yang mengalami hipertensi terbanyak pada hipertensi stage 2 sebanyak $38 \%$. Berdasarkan hasil uji chisquare diperoleh nilai signifikan 0.015 dimana nilai signifikan $<0.05$ yang berarti ada hubungan antara hipertensi dengan penurunan fungsi kognitif pada lansia.

Pada penelitian ini didapatkan nilai koefisien korelasi 0.387 yang berarti nilai koefisien korelasi cukup sehingga terdapat faktor lain yang mempengaruhi fungsi kognitif selain hipertensi. Faktor lain yang mempengaruhi fungsi kognitif diantaranya usia, lingkungan, jenis kelamin. Usia yang semakin meningkat akan diikuti oleh perubahan dan penurunan fungsi anatomi seperti semakin menyusutnya otak, dan perubahan biokimiawi di sistem saraf pusat sehingga dengan sendirinya dapat mempengaruhi fungsi kognitif (Mongsidi et al, 2012). Pengalaman di dunia pendidikan berkolerasi dengan skor pada tes-tes intelegensi dan tugas-tugas pengolahan informasi seperti memori (Alken Morgan, Sims \& Whitfield dalam McGraw, 2012). Penelitian yang dilakukan oleh Hartati \& Widayanti mengatakan bahwa tingkat pendidikan merupakan salah satu faktor resiko terhadap gangguan fungsi kognitif.
Tingkat pendidikan bukan merupakan faktor utama tetapi tingkat pendidikan dapat membantu lansia untuk menyelesaikan tugas dengan baik (Hartati \& Widayanti, 2010).

Faktor jenis kelamin juga dapat berpengaruh terhadap fungsi kognitif. Wanita lebih banyak mengalami penurunan fungsi kognitif dikarenakan tingginya angka harapan hidup wanita sehingga jumlah wanita yang berusia tua berjumlah lebih banyak, sehingga semakin tinggi umur maka akan meningkatkan terjadinya penurunan fungsi kognitif (Rasyid et al, 2017 dalam Santrock, 2017).

\section{SIMPULAN DAN SARAN}

\section{Simpulan}

Berdasarkan hasil penelitian yang telah dilakuan maka didapatkan kesimpulan: Tingkat hipertensi didapatkan lansia menderita hipertensi stage 1 sebanyak 21 responden (60,0\%). Fungsi kognitif lansia di didapatkan lansia memiliki fungsi kognitif yang masih normal sebanyak 22 responden $(62.9 \%)$. Hubungan hipertensi dengan fungsi kognitif pada lansia di UPTD Panti Sosial Rehabilitasi Lanjut Usia dan Pemeliharaan Makam Pahlawan Ciparay Kabupaten Bandung tahun 2019 dari 35 lansia didapatkan hasil: $p=0.022$ yang artinya $\mathrm{HO}$ ditolak, sehingga dalam penelitian ini terdapat hubungan yang signifikan antara hipertensi dengan fungsi kognitif pada lansia di UPTD Panti Sosial 
Rehabilitasi Lanjut Usia dan Pemeliharaan

Makam Pahlawan Ciparay Kabupaten

Bandung tahun 2019.

\section{Saran}

Bagi pihak panti sosial dapat meningkatkan pelayanan yang berhubungan hipertensi dengan cara memberikan konseling dan juga pemberian terapi antihipertensi secara tepat, serta dapat memberikan motivasi lansia untuk aktif mengikuti kegiatan berkaitan dengan fungsi kognitif pada lansia. Bagi peneliti selanjutnya diharapkan dapat menjadi dasar bagi peneliti selanjutnya, untuk meneliti faktorfaktor lain yang berhubungan dengan fungsi kognitif pada lanjut usia serta diharapkan dapat mengobservasi mengenai hipertensi dengan fungsi kognitif pada lansia.

\section{DAFTAR PUSTAKA}

Azizah, Lilik M. 2011. Keperawatan Lanjut Usia. Yogyakarta: Graha Ilmu.

Depkes RI. 2006. Pedoman Teknis Penemuan dan Tatalaksana Penyakit Hipertensi.

Ekasari M, Dkk. 2018. Meningkatkan Kualitas Hidup Lansia Konsep dan Berbagai Strategi Intervensi. Jakarta: Wineka Media.

Notoatmodjo, Soekidjo. 2010. Ilmu Perilaku Kesehatan. Jakarta: Rineka Cipta

Nugroho, Wahyudi. 2016. Keperawatan Gerontik. Jakarta: EGC

Santrock, John W. Perkembangan Masa Hidup. 2012. Edisi 13 Jilid 2. Jakarta: Erlangga

Taraghi, Zohreh, Akbari Ahmad Ali et al. 2016. Cognitive Impairment Among Elderly Patients with Chronic Heart
Failure and Related Factors. Iran J psychiatry behave sci 2016 jun; 10(2): e4500. Published Online 2016

(https://www.ncbi.nlm.nih.gov/pmc/articles/ pmc5087256/\#_ffn_sectitle) diakses pada 29 Juli 2019.

Triani, Lilis dkk. 2012. Hubungan Antara Tingkat Pendidikan dan Dukunan Keluarga Terhadap Kepatuhan Berobat Pada Penderita Hipertensi di Puskesmas Ngaliyan Semarang [Jurnal]. Stikes telogorejo semarang

Triyanto, Endang. 2014. Pelayanan Kesehatan Bagi Penderita Hipertensi Secara Terpadu. Yogyakarta: Graha Ilmu.

Ummah, Ac. 2016. Hubungan Kebutuhan Spiritual Dengan Kualitas Hidup Pada Lansia di Panti Werdha Kota Semarang [Skripsi]. Semarang: Universitas Diponegoro.

United Nations. 2015. World Population Ageing. http://www.un.org/en/development/desa/ populati on/publications/pdf/ageing/WPA@2015 higlght s.pdf. Diakses pada tanggal 12 Maret 2019.

Wahyuniarti Anisa et al. 2013. Hubungan Antara Hipertensi Dengan Penurunan Fungsi Kognitif Pada Lansia. Fakultas Kedokteran Universitas Muhammadiyah Malang.

Wahyuningsi., Astuti, Endri. 2013. Faktor Yang Mempengaruhi Hipertensi Pada Lansia. Journal ners and midwifery Indonesia. ISSN2354-7642 